\title{
PENGARUH MODEL PEMBELAJARAN KOOPERATIF TIPE TEAM ASSISTED INDIVIDUALIZATION (TAI) TERHADAP KEMAMPUAN KOMUNIKASI MATEMATIS SISWA SMP
}

\author{
Nila Mona Silalahi \\ Universitas Katolik Santo Thomas, Medan; \\ monasilalahi5@gmail.com
}

\begin{abstract}
Abstrak. Tujuan penelitian ini adalah untuk (1) mengetahui pengaruh model pembelajaran kooperatif tipe Team Assisted Individualization (TAI) terhadap kemampuan komunikasi matematis siswa; (2) mengetahui apakah kemampuan komunikasi matematis siswa dengan model pembelajaran kooperatif tipe Team Assisted Individualization (TAI) lebih tinggi daripada kemampuan komunikasi matematis siswa dengan pembelajaran konvensional. Jenis penelitian ini adalah penelitian eksperimen dengan menggunakan desain penelitian pretest-postest control group. Populasi penelitian adalah seluruh siswa kelas VII SMP Negeri 2 Pancur Batu yang terdiri dari delapan kelas. Sampel penelitian dipilih menggunakan teknik simple random sampling, sehingga diperoleh kelas VII-3 sebagai kelas eksperimen dan kelas VII-5 sebagai kelas kontrol dengan masing-masing jumlah siswa sebanyak 32 siswa. Data yang digunakan dalam penelitian ini adalah data kuantitatif. Berdasarkan analisis data penelitian, diperoleh hasil sebagai berikut: (1) hasil analisis dan regresi diperoleh bahwa pengaruh model pembelajaran kooperatif tipe TAI berpengaruh positif dengan koefisisen korelasi 0,741 dan koefisien determinasi sebesar 54,8 \%; (2) hasil analisis uji-t dengan nilai thitung $=5,643$ dan tabel $=1,669$ yang artinya thitung $>$ tabel, maka hipotesis Ho ditolak. Sehingga dapat disimpulkan bahwa kemampuan komunikasi matematis siswa yang diajar dengan model pembelajaran kooperatif tipe TAI lebih tinggi daripada kemampuan komunikasi matematis siswa yang diajar dengan pembelajaran konvensional.
\end{abstract}

Kata kunci. Komunikasi matematis, Team Assisted Individualization

Abstract. The purpose of this study was to (1) determine the effect of the cooperative learning model type Team Assisted Individualization (TAI) on students' mathematical communication skills; (2) find out whether the

Cartesius: Jurnal Pendidikan Matematika Vol. 2, No. 1

CProdi Pendidikan Matematika Universitas Katolik Santo Thomas 
mathematical communication skills of students with the cooperative learning model Team Assisted Individualization (TAI) type are higher than the mathematical communication skills of students with conventional learning. This type of research is experimental research using the pretest-posttest control group research design. The study population was all seventh grade students of Pancur Batu 2 Junior High School consisting of eight classes. The research sample was selected using simple random sampling technique, so that class VII3 was obtained as the experimental class and class VII-5 as the control class with each number of students as many as 32 students. The data used in this study are quantitative data. Based on the analysis of research data, the following results were obtained: (1) the results of analysis and regression obtained that the influence of cooperative learning type TAI (Team Assisted Individualization) had a positive effect with a correlation coefficient of 0.741 and a determination coefficient of $54.8 \%$; (2) the results of the $t$-test analysis with the value of $t$ count $=5.643$ and $t$ table $=1.669$ which means $t$ count $>t$ table, then the hypothesis Ho is rejected. So that it can be concluded that the mathematical communication skills of students taught by cooperative learning model type TAI (Team Assisted Individualization) are higher than the mathematical communication skills of students who are taught by conventional learning.

Keywords. Mathematical communication, Team Assisted Individualization

\section{PENDAHULUAN}

Setiap manusia akan selalu memerlukan suatu pendidikan. Pendidikan itu merupakan kebutuhan manusia selama manusia itu hidup [1]. Tanpa adanya pendidikan, maka manusia dalam menjalani kehidupannya tidak akan dapat berkembang dan bahkan akan menjadi terbelakang. Maka, pendidikan adalah salah satu aspek dalam kehidupan ini yang memiliki peranan penting, terutama dalam meningkatkan kualitas sumber daya manusia. Kualitas SDM suatu negara akan meningkat dengan mutu pendidikan yang bagus. Hal ini tentu tidak lepas dari peran seorang guru yang akan memberikan pendidikan kepada setiap peserta didik. Salah satu bidang pendidikan yang penting dan perlu mendapat perhatian serius adalah matematika.

Matematika merupakan salah satu bidang studi yang ada pada semua jenjang pendidikan, mulai dari tingkat pendidikan paling dasar sampai ke

Cartesius: Jurnal Pendidikan Matematika Vol. 2, No. 1

CProdi Pendidikan Matematika Universitas Katolik Santo Thomas 
jenjang perguruan tinggi. Matematika sebagai salah satu mata pelajaran yang diajarkan di sekolah yang memerlukan metode-metode pembelajaran yang efektif agar komunikasi matematis siswa sesuai dengan apa yang diharapkan [2]. Selain itu matematika merupakan salah satu mata pelajaran yang harus dipelajari siswa melalui suatu upaya atau serangkaian aktivitas dalam pembelajaran, sehingga siswa dapat mengembangkan pola pikirnya, dan dapat memecahkan masalah dalam kehidupan sehari-hari [3]. Jadi, matematika merupakan ilmu pengetahuan yang bukan hanya sebagai alat untuk berpikir tetapi juga sebagai alat untuk menyampaikan argumen atau ide-ide melalui komunikasi.

Matematika merupakan salah satu bidang studi yang sangat penting dalam dunia pendidikan. Pentingnya mempelajari matematika disesuaikan dengan tujuan dari pembelajaran matematika. Tujuan umum pembelajaran matematika yang dirumuskan NCTM yaitu (1) belajar untuk berkomunikasi (mathematical communication), (2) belajar untuk bernalar (mathematical reasoning), (3) belajar untuk memecahkan masalah (mathematical problem solving), (4) belajar untuk mengaitkan ide (mathematical connections), (5) pembentukan sikap positif terhadap matematika (positive attitudes toward mathematics) [4]. Maka jelas bahwa komunikasi matematis adalah hal yang sangat penting karena merupakan salah satu kemampuan yang harus dimiliki oleh peserta didik. Komunikasi matematika merupakan proses esensial pembelajaran matematika. Hal itu dikarenakan melalui komunikasilah, siswa merenung, memperjelas dan memperluas ide dan pemahaman tentang hubungan dan argumen matematika [5].

Kemampuan komunikasi matematis siswa perlu menjadi perhatian dalam pembelajaran matematika. Berdasarkan hasil laporan survei Programme for International Student Assessment (PISA, 2015) yang merupakan program organisasi kerjasama ekonomi dan pembangunan dunia (OECD) menunjukkan bahwa pada tahun 2016, prestasi siswa Indonesia berada pada posisi 67 dari 74 negara yang disurvei. Skor rata-rata kemampuan matematis siswa Indonesia yaitu 386 di bawah skor rata-rata kemampuan matematis siswa di negara lainnya yaitu 490. Aspek yang dinilai dalam PISA adalah kemampuan pemahaman, pemecahan masalah (problem solving), Cartesius: Jurnal Pendidikan Matematika Vol. 2, No. 1 CProdi Pendidikan Matematika Universitas Katolik Santo Thomas 
kemampuan penalaran (reasoning), dan kemampuan komunikasi (communication). Dari hasil survei ini menunjukkan bahwa kemampuan komunikasi matematis siswa SMP di Indonesia masih rendah. Rendahnya kemampuan komunikasi ini mengakibatkan siswa sulit untuk mencerna soal-soal yang diberikan sehingga mereka tidak bisa memecahkan masalah tersebut.

Begitu pentingnya peranan matematika dalam kehidupan tidak didukung dengan fakta yang terjadi di lapangan [6]. Saat ini, khususnya di Indonesia, prestasi belajar matematika siswa sekolah menengah masih tergolong rendah. Berdasarkan hasil Ujian Nasional (UN) pada pelaksanaan Ujian Nasional (UN) tahun 2016 di Sekolah Menengah Pertama (SMP), pelajaran Matematika mengalami penurunan terbesar. Perubahannya dari 56,28 ditahun 2015, kini nilainya menjadi 50,24. Terjadinya penurunan sebesar 6,04 poin. Dari pernyataan tersebut diketahui bahwa kemampuan komunikasi matematis siswa di Indonesia dalam menyelesaikan soal-soal matematika masih rendah. Maka dalam hal ini dapat disimpulkan bahwa kemampuan komunikasi matematika sangat penting, sehingga perlu untuk ditingkatkan.

Namun, pentingnya kemampuan komunikasi matematis dalam kompetensiyang harus dimiliki tidak sejalan dengan hasil kemampuan komunikasi yang selama ini dicapai oleh SMP Negeri 2 Pancur Batu. Berdasarkan hasil pengamatan dan wawancara dengan guru mata pelajaran matematika kelas VII SMP Negeri 2 Pancur Batu diketahui bahwa kemampuan komunikasi matematis siswa masih rendah. Hal ini terlihat dari masih sedikitnya siswa yang mau bertanya ataupun menyampaikan pendapatnya pada saat pembelajaran berlangsung. Kegiatan pembelajaran matematika di SMP Negeri 2 Pancur Batu sudah dilaksanakan dengan baik. Namun, guru menyatakan masih menggunakan model pembelajaran yang berpusat pada guru atau disebut juga model pembelajaran konvensional. Pembelajaran seperti itu tidak cukup untuk meningkatkan kemampuan komunikasi matematis siswa karena siswa tidak memiliki kesempatan untuk mengembangkan ide-ide kreatif dan menemukan pola atau sifat dari gejala matematis sampai pada penarikan kesimpulan dan yang terlihat malah pada saat guru menjelaskan materi pelajaran beberapa siswa sering mengabaikan Cartesius: Jurnal Pendidikan Matematika Vol. 2, No. 1 CProdi Pendidikan Matematika Universitas Katolik Santo Thomas 
gurunya dengan memilih ribut dengan teman sebangkunya. Hal ini menunjukkan bahwa model pembelajaran yang diterapkan oleh guru tersebut membosankan, karena inilah model pembelajaran yang diterapkan haruslah dapat mempengaruhi siswa dalam mengembangkan kemampuan komunikasinya serta memahami materi pembelajaran.

Kemampuan komunikasi matematis siswa dapat dikembangkan dengan melakukan kegiatan pembelajaran dalam kelompok siswa diharapkan pada masalah untuk dicari solusinya tentang topik matematika yang mereka pelajari. Selama proses kegiatan pembelajaran itu, siswa dimungkinkan untuk berdiskusi dan mengungkapkan ide-ide yang diperoleh kepada teman sekelompoknya. Dengan cara ini siswa mendapatkan wawasan ke dalam pemikiran mereka sendiri. Dalam rangka mengkomunikasikan pemikiran mereka kepada orang lain, siswa belajar secara alami untuk merefleksikan, mengatur dan mengkonsolidasikan pemikiran mereka tentang matematika.

Siswa harus didorong untuk meningkatkan kemampuan mereka untuk mengekspresikan diri mereka secara jelas dan terpadu. Kemampuan untuk menulis tentang matematika akan sangat dipelihara di kelas. Ketika bekerja pada masalah dengan teman sekelas, siswa juga memiliki kesempatan untuk melihat perspektif dan metode lain. Mereka dapat belajar untuk memahami dan mengevaluasi pemikiran orang lain untuk membangun ide-ide tersebut. Berdasarkan uraian di atas, kegiatan pembelajaran yang sangat mungkin dalam upaya meningkatkan kemampuan komunikasi adalah pembelajaran dalam kelompok. Di mana dalam pembelajaran dalam kelompok memunungkinkan adanya interaksi dalam bentuk diskusi dan tukar pendapat. Salah satu model pembelajaran yang di dalamnya terdapat proses tersebut adalahmodel pembelajaran TAI (Team Assisted Individualization). TAI (Team Assisted Individualization) adalah salah satu tipe dari model pembelajaran kooperatif yang dikembangkan pertama kali oleh Robert E Slavin. Model pembelajaran tipe TAI ini merupakan perpaduan antara pembelajaran secara individual dan pembelajaran kelompok, dimana pada pembelajaran ini setiap siswa akan belajar secara individual mengenai materi yang sudah disiapkan oleh guru kemudian dibawakan ke dalam kelompok. Didalam kelompok setiap siswa saling membantu dalam menyelesaikan Cartesius: Jurnal Pendidikan Matematika Vol. 2, No. 1

CProdi Pendidikan Matematika Universitas Katolik Santo Thomas 
masalah, oleh kerena itu terciptalah diskusi di dalam kelompok yang akan meningkatkan kemampuan komunikasi setiap siswa.

Komunikasi adalah proses menuangkan ide atau gagasan dan pemahaman matematis menggunakan angka, gambar, dan kata, dalam beragam komunitas termasuk didalamnya guru, teman sebaya, kelompok, atau kelas [7]. Sehingga, kemampuan komunikasi matematis sangat penting bagi siswa. Tanpa komunikasi dalam matematika kita akan memiliki sedikit keterangan, data, dan fakta tentang pemahaman siswa dalam melakukan proses dan aplikasi matematika. Selain itu, tanpa kemampuan komunikasi matematis yang memadai, siswa akan kesulitan untuk menyampaikan gagasan dan ide yang ada dalam pikirannya. Oleh karena itu, penulis ingin meneliti lebih jauh dengan melakukan penelitian di SMP Negeri 2 Pancur Batu dengan judul Pengaruh Model Pembelajaran Kooperatif Tipe TAI (Team Assisted Individualization) terhadap Kemampuan Komunikasi Matematis Siswa SMP Tahun Ajaran 2017/2018.

\section{METODE}

Penelitian ini merupakan penelitian kuantitatif dengan metode penelitian eksperimen. Penelitian ini dilakukan untuk mengukur pengaruh model pembelajaran kooperatif tipe TAI terhadap kemampuan komunikasi matematis siswa SMP Negeri 2 Pancur Batu. Penelitian ini dilaksanakan di SMP Negeri 2 Pancur Batu pada semester ganjil tahun pembelajaran 2017/2018. Desain penelitian yang digunakan peneliti adalah Pretest- Posttest Control Group Design. Adapun desain tersebut digambarkan sebagai berikut:

Tabel 1. Pretest-Postest Control

\begin{tabular}{|cccc|}
\hline \multicolumn{5}{|c}{ Group Design } \\
$\mathrm{R}$ & $\mathrm{O}_{1}$ & $\mathrm{X}$ & $\mathrm{O}_{2}$ \\
$\mathrm{R}$ & $\mathrm{O}_{3}$ & - & $\mathrm{O}_{4}$ \\
\hline
\end{tabular}

Keterangan: $\mathrm{X}$ : Perlakuan model pembelajaran kooperatif tipe TAI di kelas eksperimen

$\mathrm{O}_{1}$ : Pretest kelas eksperimen

$\mathrm{O}_{2}$ : Posttest kelas eksperimen

$\mathrm{O}_{3}$ : Pretest kelas kontrol

Cartesius: Jurnal Pendidikan Matematika Vol. 2, No. 1

CProdi Pendidikan Matematika Universitas Katolik Santo Thomas 


\section{$\mathrm{O}_{4}$ : Posttest kelas control}

Adapun populasi penelitian ini adalah seluruh siswa kelas VII SMP Negeri 2 Pancur Batu tahun ajaran 2017/2018 yang terdiri dari delapan kelas, yaitu VII-1, VII-2, VII-3, VII-4, VII-5, VII-6, VII-7, VII-8. Adapun dalam pengambilan sampel secara acak dapat dilakukan dengan melalui undian. Sementara sampel yang terpilih yaitu kelas VII-3 sebagai kelas eksperimen dan VII-5 sebagai kelas kontrol.

Teknik pengumpulan data yang digunakan dalam penelitian ini adalah tes. Tes ini dibagi menjadi dua bagian yaitu: pre test dan post test. Untuk memperoleh data yang diperlukan dalam penelitian ini, penelitian menggunakan teknik Pre-test atau tes awal untuk mengetahui kemampuan awal setiap siswa. Tes ini digunakan untuk mengetahui kemampuan siswa masing - masing pada mata pelajaran matematika setelah mendapat perlakuan menggunakan model pembelajaran kooperatif tipe TAI dan kemampuan siswa yang mendapat perlakuan dengan menggunakan metode pembelajaran konvensional.

Dalam uji coba instrumen tes kemampuan komunikasi matematis siswa perlu dilakukan pengembangan uji instrumen yaitu uji validitas, uji reliabilitas, daya pembeda, dan uji tingkat kesukaran. Uji coba soal dilaksanakan di SMP Pembangunan Galang pada siswa kelas VIII-A dengan jumlah siswa 26 orang. Sedangkan validasi perangkat pembelajaran dilakukan oleh ahli (dosen) yaitu Ibu Ribka Kariani Sembiring, S.Si., M.Pd.

Teknik analisis data yang digunakan dalam penelitian ini adalah teknik analisis dengan uji perbedaan dan rata-rata populasi menggunakan uji-t dengan taraf signifikans $\sigma=0,05$ untuk menguji hipotesis. Sebelum melakukan uji-t, terlebih dahulu harus dilakukan uji prasyarat analisis. Prasyarat adalah, pertama populasi berdistribusi normal (uji normalitas) dan kedua populasi memiliki varians yang homogen (uji homogenitas) dengan bantuan aplikasi SPSS 22 for windows.

Cartesius: Jurnal Pendidikan Matematika Vol. 2, No. 1

CProdi Pendidikan Matematika Universitas Katolik Santo Thomas 
Uji statistik dalam penelitian ini menggunakan uji-t dan uji regresi yang digunakan dengan bantuan program SPSS 22 For Windows. Berikut ini akan diuraikan keterkaitan permasalahan, hipotesis dan jenis uji statistik yang digunakan dalam penelitian ini adalah sebagai berikut:

Tabel 2. Keterkaitan Permasalahan, Hipotesis dan Jenis Uji Statistik

\begin{tabular}{|c|c|c|c|}
\hline No. & Permasalahan yang Diteliti & Hipotesis & Jenis Uji Statistik \\
\hline 1. & $\begin{array}{l}\text { Apakah } \\
\text { pengaruhmodel pembelajaran } \\
\text { kooperatif tipe TAI (Team } \\
\text { Assisted } \quad \text { Individualization) } \\
\text { terhadap } \\
\text { komunikasi matematis siswa } \\
\text { SMP Negeri 2 Pancur Batu }\end{array}$ & 1 & $\begin{array}{c}\text { Analisis regresi } \\
\text { sederhana }\end{array}$ \\
\hline 2. & $\begin{array}{l}\text { Apakahmodel pembelajaran } \\
\text { kooperatif tipe TAI (Team } \\
\text { Assisted Individualization) lebih } \\
\text { tinggi dari model } \\
\text { pembelajaran konvensional } \\
\text { terhadap kemampuan } \\
\text { komunikasi matematis siswa } \\
\text { SMP Negeri } 2 \text { Pancur Batu. }\end{array}$ & 2 & Uji-t \\
\hline
\end{tabular}

\section{HASIL DAN PEMBAHASAN}

\section{HASIL}

Data yang dideskripsikan dalam penelitian ini yaitu hasil tes kemampuan komunikasi matematis siswa. Hasil tes tersebut memberikan informasi tentang kemampuan siswa sebelum dan sesudah dilakukan proses pembelajaran, baik di kelas eksperimen yang menggunakan model pembelajaran kooperatif Tipe TAI (Team Assisted Individualization) maupun di kelas kontrol yang menggunakan model pembelajaran konvensional. Secara umum deskripsi kedua kelompok data kemampuan komunikasi matematis siswa disajikan pada tabel berikut:

Tabel 3. Deskripsi Mean dan Standar Deviasi Pretes, Postes, dan N-

Gain Kemampuan Komunikasi Matematis Siswa Kelompok Eksperimen dan Kelompok Kontrol

\begin{tabular}{|c|c|c|c|c|c|}
\hline \multirow{2}{*}{$\begin{array}{l}\text { Statis } \\
\text { tik }\end{array}$} & \multicolumn{2}{|c|}{ Pretes } & \multicolumn{2}{|c|}{ Postes } & N-Gain \\
\hline & Kooperatif & Kooperatif & Kooperatif & Konven & Kooperatif Konven \\
\hline
\end{tabular}

Cartesius: Jurnal Pendidikan Matematika Vol. 2, No. 1

CProdi Pendidikan Matematika Universitas Katolik Santo Thomas 


\begin{tabular}{ccccccc}
\cline { 2 - 7 } & Tipe TAI & Tipe TAI & Tipe TAI & sional & Tipe TAI & sional \\
\hline $\begin{array}{r}\text { N } \\
\text { Rata- }\end{array}$ & 32 & 32 & 32 & 32 & 32 & 32 \\
rata & 56.41 & 80.72 & 80.72 & 64.81 & & \\
$\begin{array}{r}\text { Std. } \\
\text { Dev }\end{array}$ & 17.10 & 10.40 & 10.40 & 12.77 & & 0.32 \\
\hline
\end{tabular}

Berdasarkan tabel 3 di atas diperoleh bahwa peningkatan pembelajaran yang menggunakan model pembelajaran Kooperatif Tipe TAI (Team Assisted Individualization) sebelum proses pembelajaran nilai rata-rata sebesar 56.41 dan setelah dilaksanakan pembelajaran Kooperatif Tipe TAI (Team Assisted Individualization) menjadi 80.72 Sedangkan untuk model pembelajaran konvensional diperoleh nilai rata-rata sebelum pembelajaran adalah 56.97 dan setelah pembelajaran menjadi 64.81. Deskripsi nilai rata-rata kemampuan komunikasi matematis siswa berdasarkan pembelajaranyang menggunakan model pembelajaran Kooperatif Tipe TAI (Team Assisted Individualization) maupun pembelajaran konvensional dapat dilihat pada gambar 1 berikut ini:

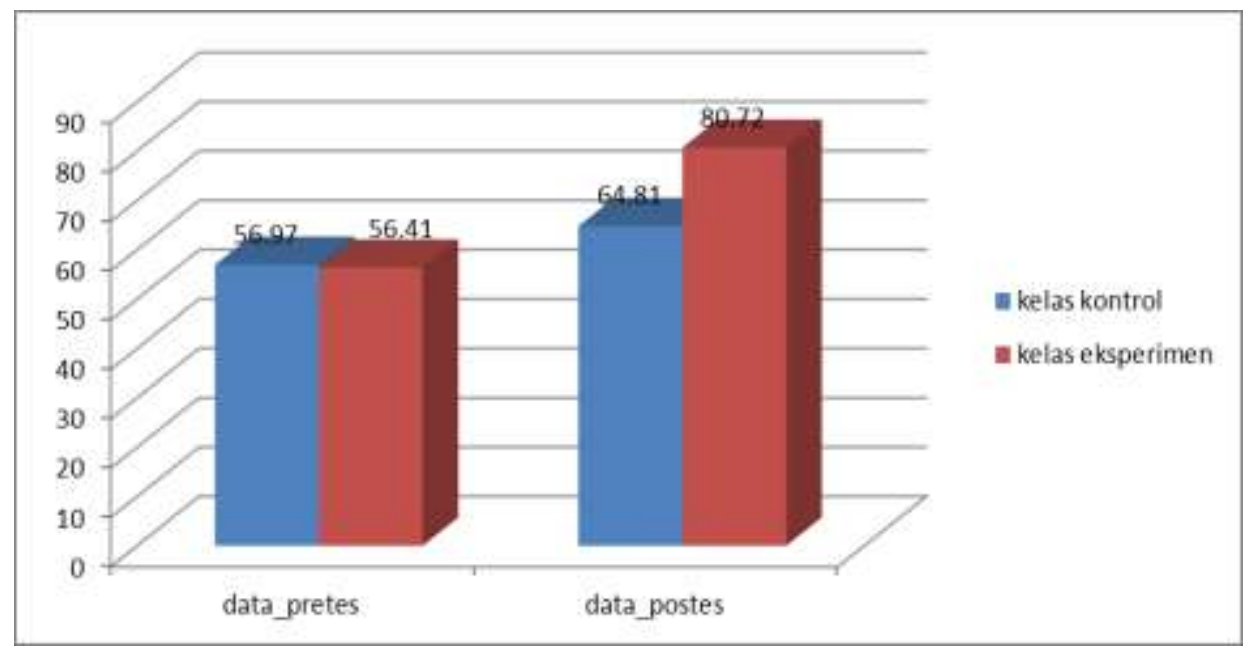

Gambar 1. Nilai Rata-Rata Kemampuan Komunikasi Matematis Siswa

Cartesius: Jurnal Pendidikan Matematika Vol. 2, No. 1

CProdi Pendidikan Matematika Universitas Katolik Santo Thomas 


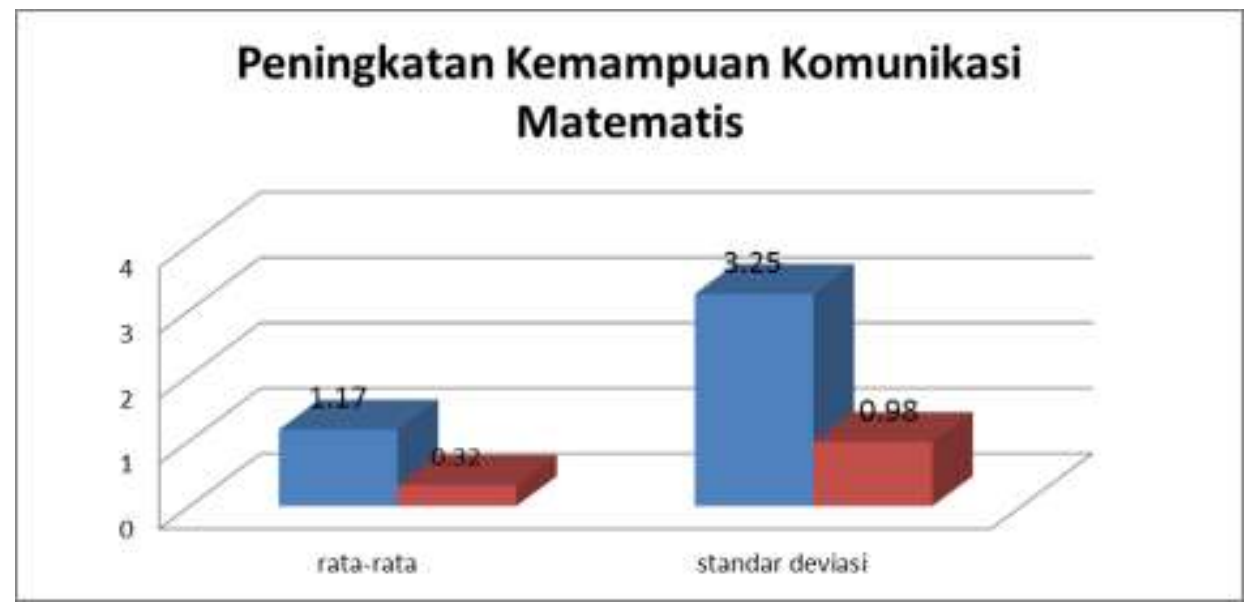

Gambar 2. Peningkatan Kemampuan Komunikasi Matematis Siswa Kelas Eksperimen dan Kelas Kontrol

Secara deskriptif ada beberapa kesimpulan yang dapat dilhat dari kemampuan komunikasi matematis siswa dari tabel 3 dan gambar 1 dan 2 yaitu:

1. Secara keseluruhan nilai rerata pretes kemampuan komunikasi matematis siswa pada kelas kontroldan kelas eksperimen sebelum di berikan perlakuan sebesar $(56,97)$ dan $(56,41)$.

2. Secara keseluruhan nilai rerata postest kemampuan komunikasi matematis siswa pada kelas eksperimen dengan menggunakan model pembelajaran kooperatif tipe TAI (Team Assisted Individualization) sebesar $(80,72)$ terlihat lebih tinggi dibandingkan dengan nilai rerata pretes kemampuan komunikasi matematis siswa pada kelas kontrol yang menggunakan pembelajaran konvensional sebesar $(64,81)$.

3. Rata-rata N-Gain kemampuan komunikasimatematis siswa dengan model pembelajaran kooperatif tipe TAI (Team Assisted Individualization) sebesar $(1,17)$ lebih tinggi dibandingkan pembelajaran menggunakan pembelajaran konvensional sebesar $(0,32)$.

Hasil perhitungan uji normalitas kemampuan awal (pretest) komunikasi matematis siswa disajikan pada tabel berikut:

Tabel 4. Hasil Uji Normalitas Pretest Kemampuan Komunikasi Matematis Siswa

\begin{tabular}{cccc}
\hline \multirow{2}{*}{ Kelas } & \multicolumn{3}{c}{ Kolmogorov-Smirnov $^{\mathrm{a}}$} \\
\cline { 2 - 4 } & Statistic & Df & Sig. \\
\hline
\end{tabular}

Cartesius: Jurnal Pendidikan Matematika Vol. 2, No. 1

CProdi Pendidikan Matematika Universitas Katolik Santo Thomas 


\begin{tabular}{cccc}
\hline eksperimen & 0.129 & 32 & 0.189 \\
Kontrol & 0.150 & 32 & 0.065 \\
\hline
\end{tabular}

Berdasarkan hasil perhitungan pada tabel 4 nilai signifikan untuk kelas eksperimen sebesar 0,189 dan nilai signifikan untuk kelas kontrol sebesar 0,065. Kedua nilai signifikan tersebut lebih besar dari taraf signifikan 0,05, sehingga dapat disimpulkan kedua kelas tersebut berdistribusi normal $\left(\mathrm{H}_{0}\right.$ ditolak).

Hasil perhitungan uji normalitas kemampuan akhir (posttest) komunikasi matematis siswa rangkumannya disajikan pada tabel 5 berikut:

Tabel 5. Uji Normalitas Postes Kelas Eksperimen dan Kelas Kontrol

\begin{tabular}{cccc}
\hline \multirow{2}{*}{ Kelas } & \multicolumn{3}{c}{ Kolmogorov-Smirnov $^{\text {a }}$} \\
\cline { 2 - 4 } & Statistic & Df & Sig. \\
\hline Eksperimen & 0.103 & 37 & 0.082 \\
Control & 0.132 & 37 & 0.185 \\
\hline
\end{tabular}

Berdasarkan hasil perhitungan pada tabel 5 nilai signifikan untuk kelas eksperimen sebesar 0,082 dan nilai signifikan untuk kelas kontrol sebesar 0,185. Kedua nilai signifikan tersebut lebih besar dari taraf signifikan 0,05, sehingga dapat disimpulkan kedua kelas tersebut berdistribusi normal $\left(\mathrm{H}_{0}\right.$ ditolak). Selanjutnya akan dilakukan uji homogenitas apakah varians keseluruhan aspek kelompok model pembelajaran Kooperatif Tipe TAI (Team Assisted Individualization) dan model konvensional sama.

Hasil uji normalitas N-Gain komunikasi matematiks siswa disajikan pada tabel berikut:.

Tabel 6. Hasil Uji Normalitas N-Gain Komunikasi Matematis Siswa

\begin{tabular}{lrrr}
\hline \multirow{2}{*}{ Kemampuan Berpikir Kritis } & \multicolumn{3}{c}{ Kolmogorov-Smirnov } \\
\cline { 2 - 4 } & Statistik & Df & \multicolumn{1}{c}{ Sig. } \\
\hline Eksperimen & 0.113 & 32 & 0.200 \\
Kontrol & 0.149 & 32 & 0.068 \\
\hline
\end{tabular}

Ho: Kelompok data berasal dari populasi yang tidak berdistribusi normal

Dari tabel 6 diperoleh nilai signifikan N-Gain kemampuan komunikasi matematis siswa untuk pembelajaran kooperatif tipe TAI sebesar 0,200 dan

Cartesius: Jurnal Pendidikan Matematika Vol. 2, No. 1

CProdi Pendidikan Matematika Universitas Katolik Santo Thomas 
pembelajaran secara konvensional sebesar 0,068. Hal ini menunjukkan bahwa data berdistribusi normal karena nilai signifikan > 0,05 sehingga hipotesis Ho ditolak.

\section{PEMBAHASAN}

Jika diamati dari koefisien variabel, penelitian ini dapat dinyatakan bahwa variabel model pembelajaran kooperatif tipe TAI (Team Assisted Individualization) dengan kemampuan komunikasi matematis memiliki korelasi yang positif. Hasil analisis yang diperoleh memberikan gambaran bahwa ternyata model pembelajaran kooperatif tipe TAI (Team Assisted Individualization) berpengaruh terhadap kemampuan komunikasi matematis siswa.

Berdasarkan hasil penelitian maka diperoleh temuan penelitian sebagai berikut:

1. Hasil analisis dan regresi diperoleh bahwa pengaruh model pembelajaran kooperatif tipe TAI (Team Assisted Individualization) dan model konvensional berpengaruh positif dengan koefisien korelasi 0,741 dan koefisien determinasi sebesar $54,8 \%$ sedangkan sisanya dipengaruhi faktor lain.

2. Hasil analisis uji perbedaan dua rerata menggunakan uji-t diperoleh nilai signifikan rerata kemampuan komunikasi matematis siswa kelas eksperimen dan kelas kontrol adalah 0,000 < 0,05, maka hipotesis Ho ditolak. Sehingga dapat disimpulkan bahwa kemampuan komunikasi matematis siswa yang memperoleh pembelajaran model pembelajaran kooperatif tipe TAI (Team Assisted Individualization) lebih tinggi daripada siswa yang memperoleh pembelajaran model konvensional.

Model pembelajaran kooperatif tipe TAI (Team Assisted Individualization) merupakan model pembelajaran yang mengabungkan pembelajaran kooperatif dan individual. Pada model ini siswa dapat mengembangkan kemampuan dan keterampilannya, adanya rasa tanggung jawab dalam kelompok dalam menyelesaikan masalah sehingga siswa yang lemah dapat terbantu dalam menyelesaikan masalahnya. Pada Proses pembelajaran ini setiap siswa secara individual belajar materi pembelajaran yang sudah

Cartesius: Jurnal Pendidikan Matematika Vol. 2, No. 1

CProdi Pendidikan Matematika Universitas Katolik Santo Thomas 
dipersiapkan oleh guru. Hasil belajar individual dibawa ke kelompokkelompok untuk didiskusikan, di periksa oleh anggota kelompok dan semua anggota kelompok bertanggung jawab atas keseluruhan jawaban. Pada tahap bediskusi dengan teman sekolompok siswa dilatih untuk mengidentifikasi suatu pernyataan, membuat langkah penyelesaian dan membuat kesimpulan. Pada saat mengoreksi jawaban teman, siswa dituntut mampu menganalisis jawaban temannya untuk menarik kesimpulanmana yang benar dan mampu mengklarifikasi jawaban yang salah.

Pembelajaran konvensional merupakan pembelajaran yang berpusat pada guru karena peran guru adalah menyiapkan dan menginformasi kepada siswa, pengenalan konsep dan pengembangannya semuanya berpusat pada guru dan siswa hanya pasif, kegiatan siswa adalah menerima, menyimpan, dan melakukan aktivitas-aktivitas lain yang sesuai dengan informasi yang diberikan. Sehingga pembelajaran konvensional ini membuat kemandirian siswa dalam mengembangkan pengetahuan dan keterampilannya akan rendah.

Dari uraian penjelasan di atas, sesuai hal yang bisa ditekankan dalam penelitian ini berkaitan dengan pengambilan metode pembelajaran yang ditetapkan dalam pembelajaran untuk meningkatkan kemampuan komunikasi matematis siswa. Bila diterjemahkan dari persamaan regresi sederhana diperoleh data dalam penelitian ini diketahui bila ingin mendapatkan kemampuan komunikasi matematis yang baik diiperlukan pemilihan model pembelajaran tepat.

\section{KESIMPULAN}

Berdasarkan analisis data hasil penelitian dan pembahasan, maka dapat disimpulkan bahwa:

1. Hasil analisis korelasi dan regresi diperoleh bahwa penerapan model pembelajaran kooperatif tipe TAI (Team Assisted Individualization) berpengaruh positif dengan koefisien korelasi 0,741 dan koefisien determinasi sebesar $54,8 \%$.

Cartesius: Jurnal Pendidikan Matematika Vol. 2, No. 1

CProdi Pendidikan Matematika Universitas Katolik Santo Thomas 
2. Hasil uji perbedaan dua rerata menggunakan uji $t$ independen diperoleh nilai signifikan rerata kemampuan komunikasi matematis siswa kelas eksperimen dan kelas kontrol adalah 0,000 < 0,05, maka hipotesis Ho ditolak. Sehingga dapat disimpulkan bahwa rerata peningkatan kemampuan komunikasi matematis siswa yang memperoleh pembelajaran dengan model pembelajaran kooperatif tipe TAI (Team Assisted Individualization) lebih tinggi daripada peningkatan kemampuan komunikasi matematis siswa yang memperoleh pembelajaran konvensional.

\section{UCAPAN TERIMAKASIH}

Penulis menyampaikan terimakasih kepada Bapak Arisan Candra Nainggolan, S.Pd., M.Pd. sebagai dosen pembimbing 1 dan Ibu Imelda, S.Pd., M.Pd. sebagai dosen pembimbing 2 yang telah mengarahkan dan membimbing penulis mulai dari awal penelitian hingga berakhirnya penelitian sehingga penulis dapat menuliskan artikel ini yang merupakan bagian dari hasil penelitian penulis. Penulis juga menyampaikan terimakasih kepada kepala program studi Pendidikan Matematika, dekan, dan rektor Universitas Katolik Santo Thomas atas dukungan yang diberikan kepada penulis.

\section{DAFTAR PUSTAKA}

[1] E. Triyanto, S. Anitah, and N. Suryani, "Peran Kepemimpinan Kepala Sekolah Dalam Pemanfaatan Media Pembelajaran Sebagai Upaya Peningkatan Kualitas Proses Pembelajaran," J. Teknol. Pendidik., Vol. 1, No. 2, pp. 226-238, 2013.

[2] N. Ubaidah, "Pemanfaatan CD Pembelajaran untuk Meningkatkan Kemampuan Komunikasi Matematis Siswa melalui Pembelajaran Make a Match," J. Pendidik. Mat. FKIP Unissula, Vol. 4, No. 1, pp. 53-70, 2016.

[3] D. Rostika and H. Junita, "Peningkatan Kemampuan Pemecahan Masalah SIswa SD dalam Pembelajaran Matematika Dengan Model Diskursus Multy Representation (DMR)," EduHumaniora J. Pendidik. Dasar, Vol. 9, No. 1, pp. 35-46, 2017.

[4] A. W. P. Fujiwijaya and A. Rahman, "Analysis of Students Communication Abilities and Mathematics Logic Thinking in Generative Learning With Scientific Approach of Class Xi Students Majoring in Health Analys At Smk Kesehatan Mega Rezky in Makassar," J. Daya Mat., Vol. 4, No. 2, pp. 218-236, 2016.

Cartesius: Jurnal Pendidikan Matematika Vol. 2, No. 1

CProdi Pendidikan Matematika Universitas Katolik Santo Thomas 
[5] N. S. I. Palino, "Pengaruh Penerapan Pembelajaran Kooperatif Tipe Think Pair Share Terhadap Kemampuan Komunikasi Matematik Siswa Kelas VIII SMP Negeri 5 Kendari," J. Penelit. Pendidik. Mat., Vol. 2, No. 1, pp. 91-106, 2015.

[6] D. A. Sholihah and A. Mahmudi, "Keefektifan Experiential Learning Pembelajaran Matematika MTs Materi Bangun Ruang Sisi Datar," J. Ris. Pendidik. Mat., Vol. 2, No. 2, pp. 175-185, 2015.

[7] Y. Yuniarti, "Pengembangan Kemampuan Komunikasi Matematis dalam Pembelajaran Matematika di Sekolah Dasar," EduHumaniora, Vol. 6, No. 2, pp. 109-114, 2014.

Cartesius: Jurnal Pendidikan Matematika Vol. 2, No. 1

CProdi Pendidikan Matematika Universitas Katolik Santo Thomas 